\title{
Electrochemical promotion of sulfur dioxide catalytic oxidation
}

\author{
Petrushina, Irina; Bandur, Viktor; Cappeln, Frederik Vilhelm; Bjerrum, Niels
}

Published in:

Journal of The Electrochemical Society

Link to article, DOI:

$10.1149 / 1.1393640$

Publication date:

2000

Document Version

Publisher's PDF, also known as Version of record

Link back to DTU Orbit

Citation (APA):

Petrushina, I., Bandur, V., Cappeln, F. V., \& Bjerrum, N. (2000). Electrochemical promotion of sulfur dioxide catalytic oxidation. Journal of The Electrochemical Society, 147(8), 3010-3013.

https://doi.org/10.1149/1.1393640

\section{General rights}

Copyright and moral rights for the publications made accessible in the public portal are retained by the authors and/or other copyright owners and it is a condition of accessing publications that users recognise and abide by the legal requirements associated with these rights.

- Users may download and print one copy of any publication from the public portal for the purpose of private study or research.

- You may not further distribute the material or use it for any profit-making activity or commercial gain

- You may freely distribute the URL identifying the publication in the public portal

If you believe that this document breaches copyright please contact us providing details, and we will remove access to the work immediately and investigate your claim. 


\title{
Electrochemical Promotion of Sulfur Dioxide Catalytic Oxidation
}

\author{
I. M. Petrushina, ${ }^{a, *, z}$ V. A. Bandur, ${ }^{b}$ F. Cappeln, ${ }^{a}$ and N. J. Bjerrum ${ }^{a},{ }^{*}$ \\ ${ }^{a}$ Materials Science Group, Department of Chemistry, Technical University of Denmark, DK-2800 Lyngby, Denmark \\ ${ }^{b}$ V.I. Vernadskii Institute of General and Inorganic Chemistry, National Academy of Sciences of Ukraine, Kiev, Ukraine
}

\begin{abstract}
The effect of electrochemical polarization on the catalytic $\mathrm{SO}_{2}$ oxidation in the molten $\mathrm{V}_{2} \mathrm{O}_{5}-\mathrm{K}_{2} \mathrm{~S}_{2} \mathrm{O}_{7}$ system has been studied using a gold working electrode in the temperature range $400-460^{\circ} \mathrm{C}$. A similar experiment has been performed with the industrial catalyst VK-58. The aim of the present investigation was to study a possible non-Faradaic electrochemical promotion of the liquidphase catalytic reaction. It has been shown that there are two negative potential promotion areas with maximum effects at approximately -0.1 and $-0.2 \mathrm{~V}$, and one positive potential promotion area with the maximum effect between 0.1 and $0.3 \mathrm{~V}$. There were no Faradaic reactions in the negative polarization region, and there was an anodic current which was less than $16 \%$ of the theoretical value for an exclusively Faradaic $\mathrm{SO}_{2}$ oxidation. Therefore the promotion effects at negative polarization are completely nonFaradaic. All the promotion effects have been explained as mainly due to charging of the electric double layer at the gold electrode. The effect at $-0.2 \mathrm{~V}$ also depends on the $\mathrm{V}_{2} \mathrm{O}_{5}$ concentration and is more pronounced at higher $\mathrm{V}_{2} \mathrm{O}_{5}$ concentrations. This has been ascribed to a destruction of the vanadium polymeric chains caused by the negative charge on the electrode. The Faradaic part of the promoting effect under positive polarization has been explained as the electrochemical pushing of the $V(V) \leftrightarrow V(I V)$ equilibrium in the direction of $\mathrm{V}(\mathrm{V})$ formation. It has also been shown that when using the industrial VK-58 catalyst the activity can be increased up to four times by using the negative polarization effect with maximum at $-0.2 \mathrm{~V}$.
\end{abstract}

(c) 2000 The Electrochemical Society. S0013-4651(99)10-023-5. All rights reserved.

Manuscript submitted October 4, 1999; revised manuscript received February 29, 2000.

The present work is a continuation of our investigation of the electrochemistry of the molten $\mathrm{V}_{2} \mathrm{O}_{5}-\mathrm{M}_{2} \mathrm{~S}_{2} \mathrm{O}_{7}$ system ( $\mathrm{M}$ is an alkali metal). ${ }^{1-3}$ This melt has been found to be a realistic model of the $\mathrm{V}_{2} \mathrm{O}_{5}-\mathrm{M}_{2} \mathrm{~S}_{2} \mathrm{O}_{7}$ catalyst for sulfur dioxide oxidation with air which is used in sulfuric acid production and $\mathrm{SO}_{2}$ removal from flue gases. It has been shown $n^{1-3}$ that electrochemical measurements can provide important information about the vanadium complexes formed in the $\mathrm{K}_{2} \mathrm{~S}_{2} \mathrm{O}_{7}-\mathrm{V}_{2} \mathrm{O}_{5}$ and $\mathrm{K}_{2} \mathrm{~S}_{2} \mathrm{O}_{7}-\mathrm{KHSO}_{4}-\mathrm{V}_{2} \mathrm{O}_{5}$ molten systems and thus provide some insight concerning the reaction mechanism during catalysis. It has also been concluded that the voltammetric technique can be used to examine the alkali ion promotion effect on the $\mathrm{V}(\mathrm{V}) \leftrightarrow$ $\mathrm{V}(\mathrm{IV})$ reaction in this system. ${ }^{3}$

Alkali promoters are widely employed for catalytic reactions in order to improve activity, selectivity, and stability of the catalysts, but the mechanism of their physical and chemical effects has not been established in all cases. ${ }^{4}$ Knowledge about the nature of the promoting effect is very valuable because it gives the opportunity for fast optimization of industrial catalysts. The fact that a catalyst is often a system which consists of an electronic and an ionic conductor makes it possible to use electrochemical techniques to study the nature of the promotion effect in catalysts. Application of galvanic cells with solid electrolytes for the study of catalytic phenomena was suggested by Wagner. ${ }^{5}$ This approach was also used in the solidelectrolyte potentiometry for measuring the oxygen activity of metal catalysts in situ. Progress in this area has been described in several reviews. ${ }^{6-8}$ It was also found that it is possible to promote catalytic reactions electrochemically. This phenomenon was named by Vayenas as the "NEMCA-effect" (non-Faradaic electrochemical modification of catalytic activity).., 10 The term "electrochemical promotion" was first proposed by Pritchard et al. ${ }^{11}$ in their comment on Vayenas's paper. ${ }^{9}$ The effect of polarization on the activity of metal catalysts on ionic conductive supports was studied by Vayenas et al. ${ }^{9,10}$ It has been shown that the catalytic activity and selectivity of porous metals can be significantly enhanced by having the catalytic reaction take place in a solid electrolyte cell. Chekryshkin et $a .^{12}$ studied the catalytic oxidation on a liquid-phase catalyst under the conditions of electrolysis, i.e., in this case Faradaic (electrochemical) reactions took place. It was shown that electrolysis can improve the activity and selectivity of molten $\mathrm{KVO}_{3}-\mathrm{V}_{2} \mathrm{O}_{5}$ catalysts for ethanol conversion to ethene, ethanal, or $\mathrm{CO}_{2}$.

\footnotetext{
* Electrochemical Society Active Member.

z E-mail: impetr@kemi.dtu.dk
}

In the present paper the non-Faradaic electrochemical promotion of a liquid-phase catalytic reaction has been studied. The $\mathrm{SO}_{2}$ oxidation when using a molten $\mathrm{V}_{2} \mathrm{O}_{5}-\mathrm{K}_{2} \mathrm{~S}_{2} \mathrm{O}_{7}$ catalyst has been chosen as a model liquid-phase catalytic reaction. We assumed that there should be a difference in the non-Faradaic electrochemical promotion of solid-phase and liquid-phase catalytic reactions. In solidphase catalysis with the NEMCA effect, the catalyst is an electronic conductor, i.e., a polarized electrode, and the support is an ionic conductor, i.e., electrolyte. According to Vayenas et al., the polarization of the catalyst affects its activity in the following way: it accelerates the oxide transport through the support (oxygen pump) and creates a different type of weakly bonded (and therefore more active) oxygen adsorbed on the surface of the catalyst.

In the case of liquid-phase catalysis it is not the catalyst which is polarized but an otherwise catalytically inactive electrode. The catalyst itself plays the role of the electrolyte. If no Faradaic reactions take place in this type of system, the only way polarization can affect the catalytic activity is by a change in the structure of the electric double layer at the working electrode.

\section{Experimental}

Pure and dry $\mathrm{K}_{2} \mathrm{~S}_{2} \mathrm{O}_{7}$ was prepared by thermal decomposition of $\mathrm{K}_{2} \mathrm{~S}_{2} \mathrm{O}_{8}$ (Merck, pro analysis, maximum $0.001 \%$ by weight $\mathrm{N}$ ) as described earlier. ${ }^{13} \mathrm{~V}_{2} \mathrm{O}_{5}$ from Cerac (99.9\% pure by weight) was used without further purification. All sample preparation and handled were performed in an argon-filled glove box (Vacuum Atmospheres, Inc.), with a measured oxygen and water concentration of less than $10 \mathrm{ppm}$. Each compartment of the electrochemical cell used contained $21 \mathrm{~g}$ of catalyst.

Commercial gases $\mathrm{SO}_{2}(>99.9 \%), \mathrm{O}_{2}\left(99.8 \% \mathrm{O}_{2}+0.2 \% \mathrm{~N}_{2}\right.$ and $\mathrm{Ar})$, and $\mathrm{N}_{2}\left(<40 \mathrm{ppm} \mathrm{O}_{2}+\mathrm{H}_{2} \mathrm{O}\right)$ were used.

The construction of the electrochemical cell is given in Fig. 1. The cell consists of two Pyrex compartments connected with a Pyrex filter (pore size no. 4). Gold wire spirals sealed in Pyrex tubes served as working and counter electrodes. It has been shown previously that gold is not catalytically or electrocatalytically active during $\mathrm{SO}_{2}$ oxidation. ${ }^{1-3}$ The gold wire spirals were inserted into Pyrex tubes of a larger diameter that also served as inlets for the gases. The third gold wire electrode inserted in the counter electrode compartment outside the gas inlet tube was used as a quasi-reference electrode. It has been shown in our own publications ${ }^{1-3}$ that in the studied media the potential of the gold electrode is defined by the redox couple $V(V) \leftrightarrow V(I V)$. This reaction is reversible and the reference electrode has a stable potential. The same reference electrode was used recently with equal- 
ly good results. ${ }^{14}$ The zero current potential of the working electrode was also zero because both the potential of the reference electrode and the potential of the working electrode were defined by the $\mathrm{V}(\mathrm{V}) / \mathrm{V}(\mathrm{IV})$ redox couple. The working electrode gas composition was $10 \%$ $\mathrm{SO}_{2} / 18 \% \mathrm{O}_{2} / 72 \% \mathrm{~N}_{2}$, and the gas composition of the counter and the reference electrodes was $20 \% \mathrm{O}_{2} / 80 \% \mathrm{~N}_{2}$. Mass flowmeters $(5850 \mathrm{~S}$ Brookssmart) and 0154 Brooks Instrument controller controlled the inlet gas compositions. Both inlet gas mixture flow rates were 100 $\mathrm{mL} / \mathrm{min}$. The $\mathrm{SO}_{2}$ concentration in the outlet gas mixture was measured by a Shimadzu GC 8A gas chromatograph (GC) with a thermal conductivity detector and $8 \mathrm{ft} \times 1 / 8$ in. SS stainless steel columns packed with Porapak Q (50-80 mesh) before the experiment calibration with known $\mathrm{SO}_{2}$ volume concentration was carried out. The carrier was $\mathrm{He}$, and the column and detector temperatures were set at 140 and $160^{\circ} \mathrm{C}$, respectively. The GC was operated isothermally and was connected via an interface to a computer. Homemade software was used for integrating the chromatographic peak areas.

The cell was placed in a vertical copper-aluminum-block furnace with temperature regulation to within $\pm 1^{\circ} \mathrm{C} . .^{15}$ The gas was bubbled through the melt. The temperatures of the experiments were 440 or $460^{\circ} \mathrm{C}$.

An EG\&G PAR 283 potentiostat/galvanostat controlled by 352 SoftCorr ${ }^{\mathrm{TM}}$ III software was used for electrode polarization. The initial (at zero polarization) catalytic activity was measured after the turnover frequency (number of converted $\mathrm{SO}_{2}$ moles per mole of

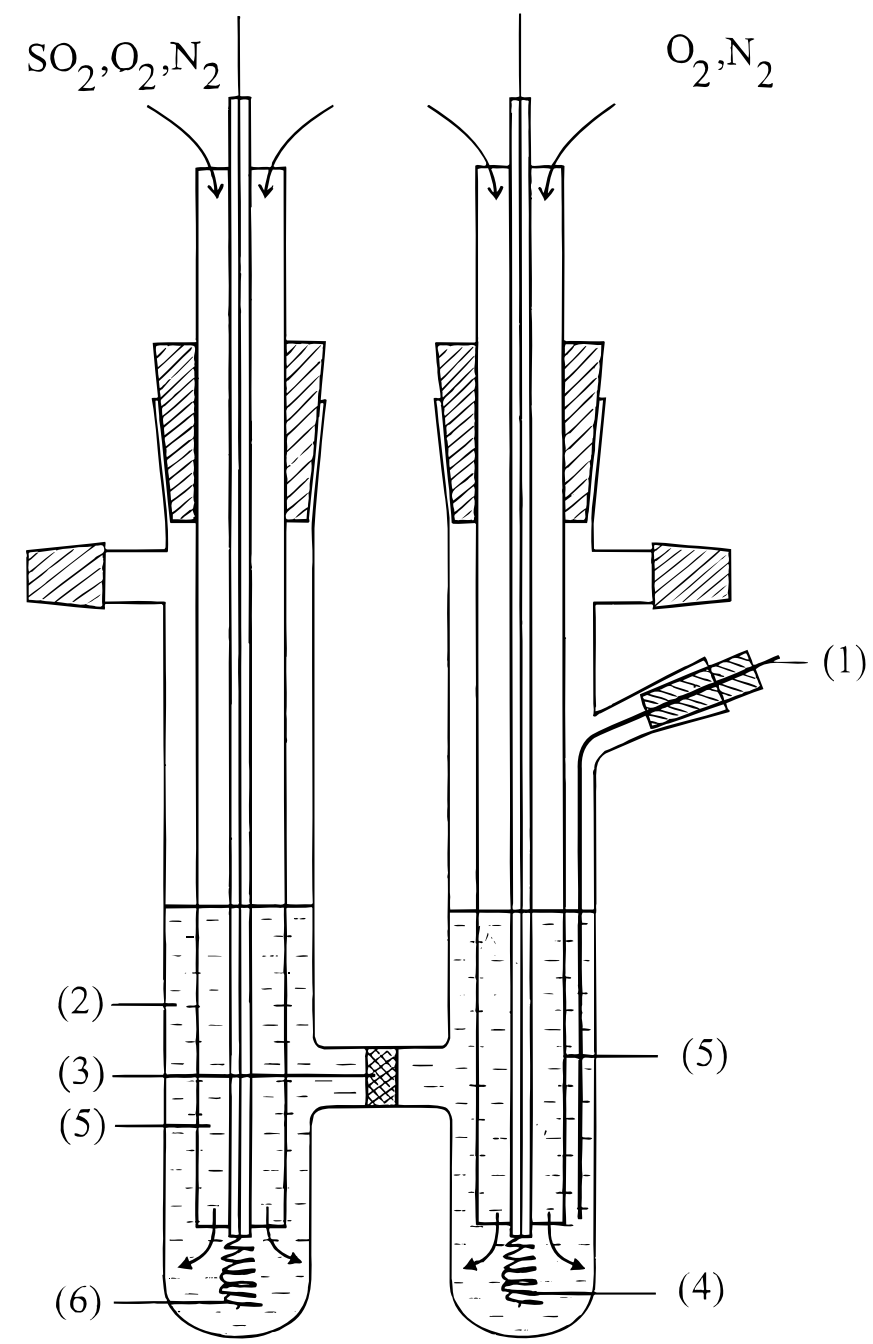

Figure 1. Electrochemical cell: (1) reference electrode, (2) molten catalyst, (3) porous Pyrex membrane, (4) counter electrode, (5) gas inlet Pyrex tube, (6) working electrode.
$\mathrm{V}_{2} \mathrm{O}_{5}$ per second) had stabilized, i.e., under steady-state conditions. For each value of polarization the measurements were performed after stabilization of the turnover frequency (6-24 h). Turnover frequency $v s$. polarization curves were reproduced for each studied $\mathrm{V}_{2} \mathrm{O}_{5}$ concentration and temperature.

A theoretical current value for Faradaic $\mathrm{SO}_{2} \rightarrow \mathrm{SO}_{3}$ oxidation was calculated using Faraday's law and the value of maximum turnover frequency at positive (anodic) polarization.

\section{Results and Discussion}

The catalytic activity of the $\mathrm{V}_{2} \mathrm{O}_{5}-\mathrm{K}_{2} \mathrm{~S}_{2} \mathrm{O}_{7}$ molten catalyst with and without polarization has been measured at 440 and $460^{\circ} \mathrm{C}$. The stable conversion values were obtained at each temperature in the time interval 2-24 h, indicating that steady-state conditions had been obtained. The results are given in Fig. 2 and 3. It can be seen from Fig. 2 and 3 that there are two negative potential promotion areas with maximum effects at $\approx-0.1 \mathrm{~V}$ (peak II) and at $\approx-0.2 \mathrm{~V}$ (peak I), and one positive potential promotion area with the maximum effect between $0.1-0.3 \mathrm{~V}$ (peak III). It can be seen that the catalytic activity (turnover frequency) of $\mathrm{V}_{2} \mathrm{O}_{5}$ at zero polarization also increases with $\mathrm{V}_{2} \mathrm{O}_{5}$ concentration and temperature. Both negative and positive polarization causes a two- to fourfold increase in the catalytic effect of $\mathrm{V}_{2} \mathrm{O}_{5}$ (Fig. 2 and 3).

In the case of $\mathrm{a} \mathrm{V}_{2} \mathrm{O}_{5}$ concentration of $10 \mathrm{~mol} \% \mathrm{~V}_{2} \mathrm{O}_{5}$ there is with an increase in temperature, a decrease in both negative potential promotion effects (peaks I and II), and an increase in the positive potential promotion effect (peak III) (Fig. 2). With increasing $\mathrm{V}_{2} \mathrm{O}_{5}$ concentration at constant temperature $\left(460^{\circ} \mathrm{C}\right)$ peaks II and III have almost the same value while peak $\mathrm{I}$ is significantly increased (Fig. 3). It can be also seen from Fig. 3 that there is a change in the potential of maximum promotion effect with concentration.

Figure 4 shows a steady-state voltammetric curve which corresponds to the investigation with $10 \mathrm{~mol} \% \mathrm{~V}_{2} \mathrm{O}_{5}$ at $440^{\circ} \mathrm{C}$. It can be seen that the current is approximately zero at negative polarization $(<5$ $\mathrm{mA} / \mathrm{cm}^{2}$ ), meaning that the promotion effect associated with the peaks I and II is of a non-Faradaic nature. The promotion effects with maximum in this range (i.e., at -0.1 and $-0.2 \mathrm{~V}$ ) must be attributed to the charge of the double layer at the working gold electrode, i.e., a pure non-Faradaic effect. We can assume that vanadium complexes are pre-

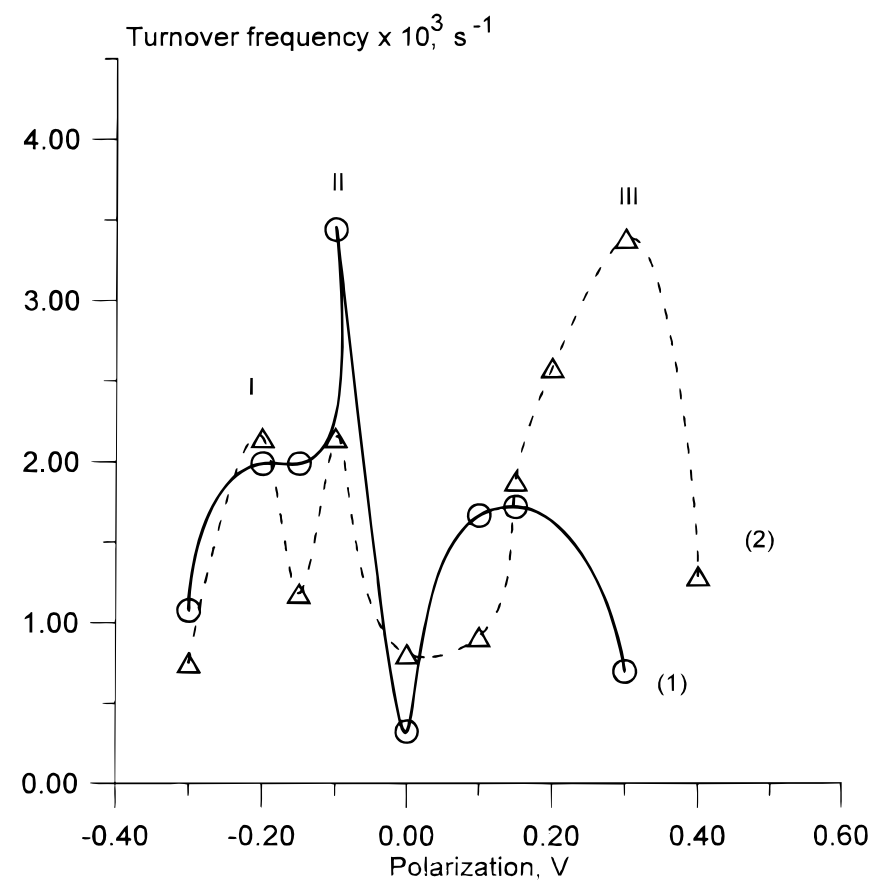

Figure 2. Turnover frequency of $\mathrm{SO}_{2}$ catalytic oxidation [mol $\mathrm{SO}_{2}$ (conv.)/ $\left./ \mathrm{mol} \mathrm{V}_{2} \mathrm{O}_{5} / \mathrm{s}\right]$ vs. working electrode polarization for the molten $10 \mathrm{~mol}$ $\% \mathrm{~V}_{2} \mathrm{O}_{5}-90 \mathrm{~mol} \% \mathrm{~K}_{2} \mathrm{~S}_{2} \mathrm{O}_{7}$ catalyst at (1) $440^{\circ} \mathrm{C}$ and (2) $460^{\circ} \mathrm{C}$. 


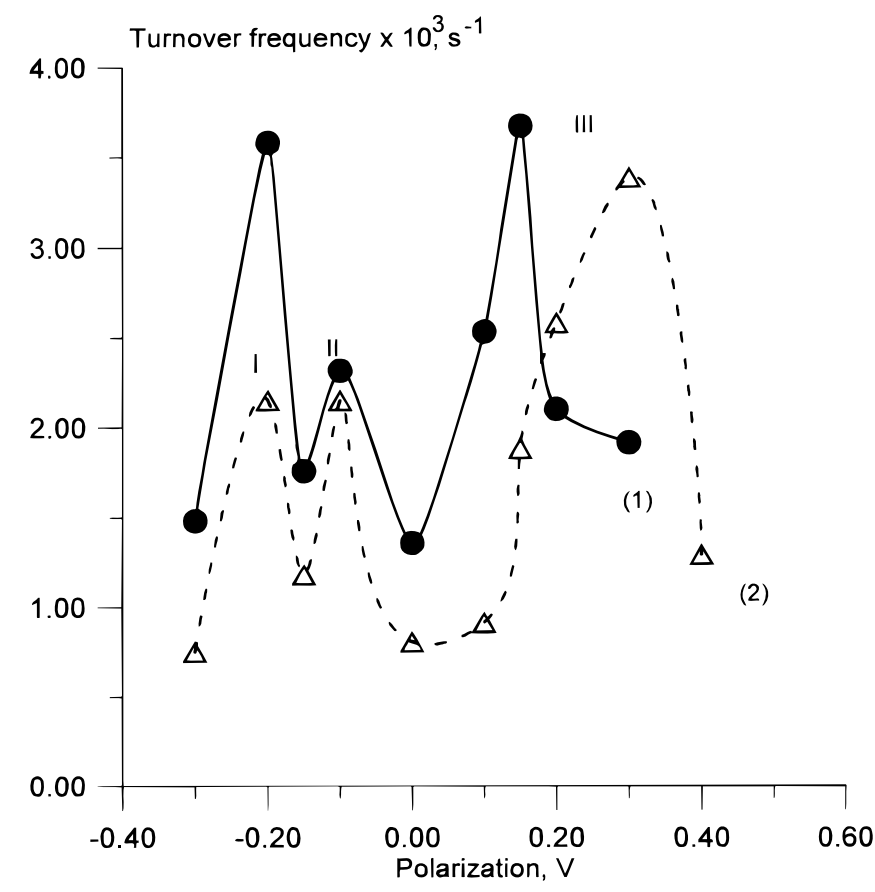

Figure 3. Turnover frequency of $\mathrm{SO}_{2}$ catalytic oxidation [mol $\mathrm{SO}_{2}$ (conv.) $\left./ \mathrm{mol} \mathrm{V}_{2} \mathrm{O}_{5} / \mathrm{s}\right] v$ s. working electrode polarization for the (1) $17 \mathrm{~mol} \%$ $\mathrm{V}_{2} \mathrm{O}_{5}-83 \mathrm{~mol} \% \mathrm{~K}_{2} \mathrm{~S}_{2} \mathrm{O}_{7}$ catalyst at $460^{\circ} \mathrm{C}$ and for (2) $10 \mathrm{~mol} \% \mathrm{~V}_{2} \mathrm{O}_{5}-$ $90 \mathrm{~mol} \% \mathrm{~K}_{2} \mathrm{~S}_{2} \mathrm{O}_{7}$ catalyst.

sent in the melt in which vanadium atoms are surrounded with oxygen atoms in the first coordination sphere. In the case of negative polarization the atoms nearest the electrode will be the outer sphere potassium atoms, which will cause a distortion of the $\mathrm{V}-\mathrm{O}$ bond and therefore promote the catalytic reaction. Such an explanation is in agreement with the temperature dependence for the effect at the same concentration of $\mathrm{V}_{2} \mathrm{O}_{5}$ (see Fig. 2). With increasing temperature from 440 to $460^{\circ} \mathrm{C}$ (in the system $\mathrm{K}_{2} \mathrm{~S}_{2} \mathrm{O}_{7}, 10 \mathrm{~mol} \% \mathrm{~V}_{2} \mathrm{O}_{5}$ ) peak II decreases. It is natural that with an increase of temperature the influence of the outer sphere cation on the central atom will be lower (peaks I and II).

The effect at $-0.2 \mathrm{~V}$ depends also on the $\mathrm{V}_{2} \mathrm{O}_{5}$ concentration and is more pronounced at higher $\mathrm{V}_{2} \mathrm{O}_{5}$ concentration. The difference in the concentration behavior of peaks I and II can be caused by differ-

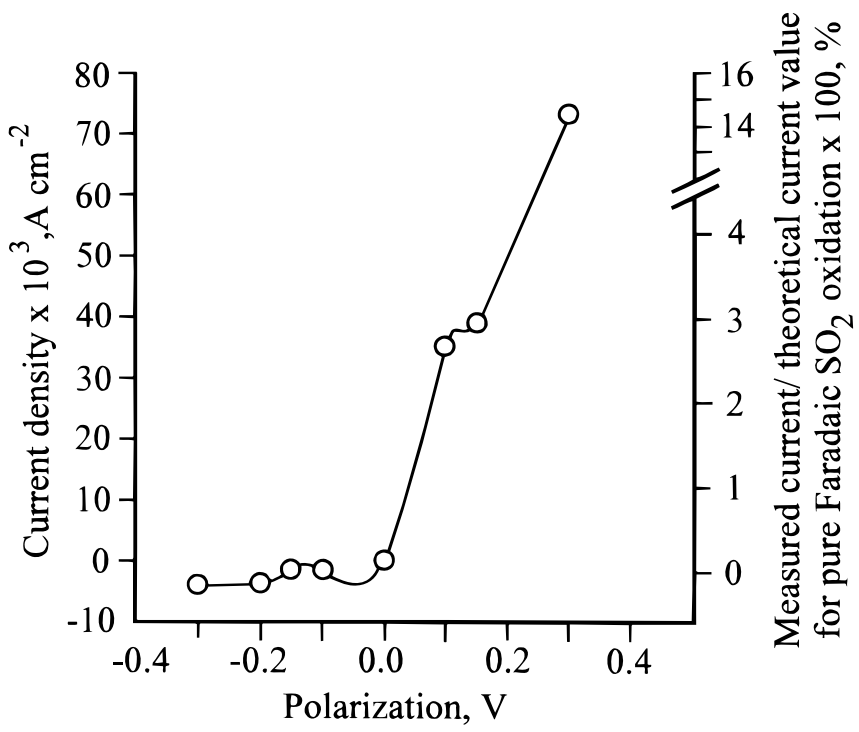

Figure 4. Stationary polarization curve obtained with $10 \mathrm{~mol} \% \mathrm{~V}_{2} \mathrm{O}_{5}-90$ mol $\% \mathrm{~K}_{2} \mathrm{~S}_{2} \mathrm{O}_{7}$ catalyst at $440^{\circ} \mathrm{C}$. ent values of the negative charge at the surface of the working electrode. The stronger the charge the more molecular layers of the molten electrolyte can be affected and the ordered structure of the electrolyte can be destroyed. The degree of polymerization of the $\mathrm{K}_{2} \mathrm{~S}_{2} \mathrm{O}_{7}-\mathrm{V}_{2} \mathrm{O}_{5}$ melt increases with increasing $\mathrm{V}_{2} \mathrm{O}_{5}$ concentration. The existence of dimeric or polymeric complexes in such melts at a concentration higher than $\sim 12 \mathrm{~mol} \% \mathrm{~V}_{2} \mathrm{O}_{5}$ was confirmed by nuclear magnetic resonance (NMR) measurements. ${ }^{16}$ Therefore the concentration behavior of peak II can be caused by the destruction of the vanadium polymeric chains caused by the negative charge on the electrode. This destruction will result in lower viscosity and higher activity of the catalyst.

It can be seen from Fig. 3 that at positive potentials the current is much higher than at negative potentials. This means a start of the electrochemical reaction, which in Ref. 1 was proved to be the $\mathrm{V}(\mathrm{IV}) \rightarrow \mathrm{V}(\mathrm{V})$ oxidation. Many investigators believe that this stage is the rate-determining stage in the $\mathrm{SO}_{2}$ catalytic oxidation. ${ }^{17-22}$ Therefore, if the electrode is kept at the initial potential of the $\mathrm{V}(\mathrm{IV}) \rightarrow \mathrm{V}(\mathrm{V})$ oxidation the whole catalytic reaction can also be Faradaic promoted. However it is not a complete Faradaic promotion effect (Fig. 4) and the promotion could also be caused by charge of the electric double layer. Dependence of the peak potential on $\mathrm{V}_{2} \mathrm{O}_{5}$ concentration can be explained by changes in the Faradaic part of the promoting effect at positive polarization.

The possibility of a non-Faradaic electrochemical promotion was also shown with the industrial VK-58 catalyst (Haldor Topsoe A/S)

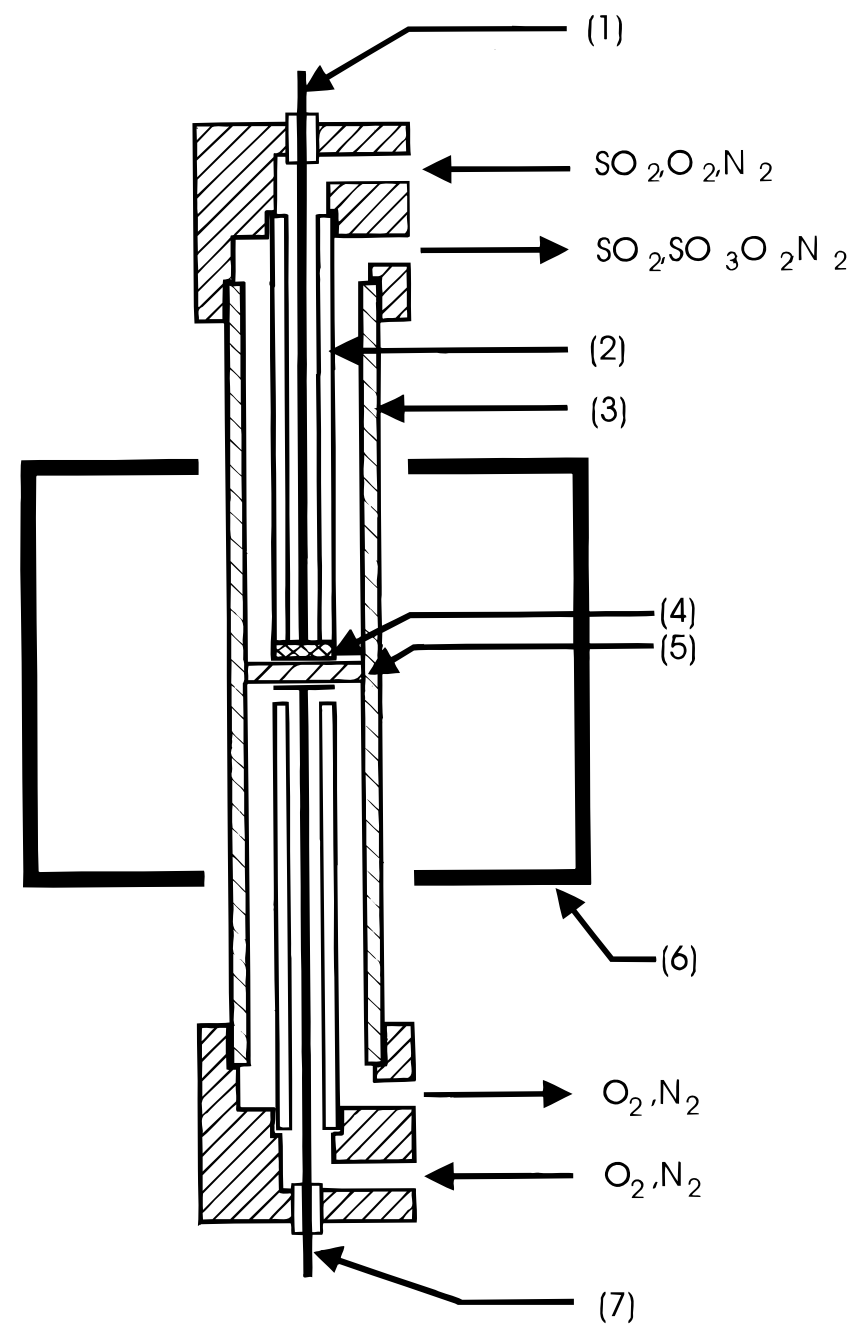

Figure 5. Electrochemical cell for study of the polarization effect on the commercial VK-58 catalyst: (1) Au working electrode, (2) quartz tube, (3) quartz cell, (4) catalyst layer, (5) quartz porous membrane, (6) furnace, (7) Au counter electrode. 


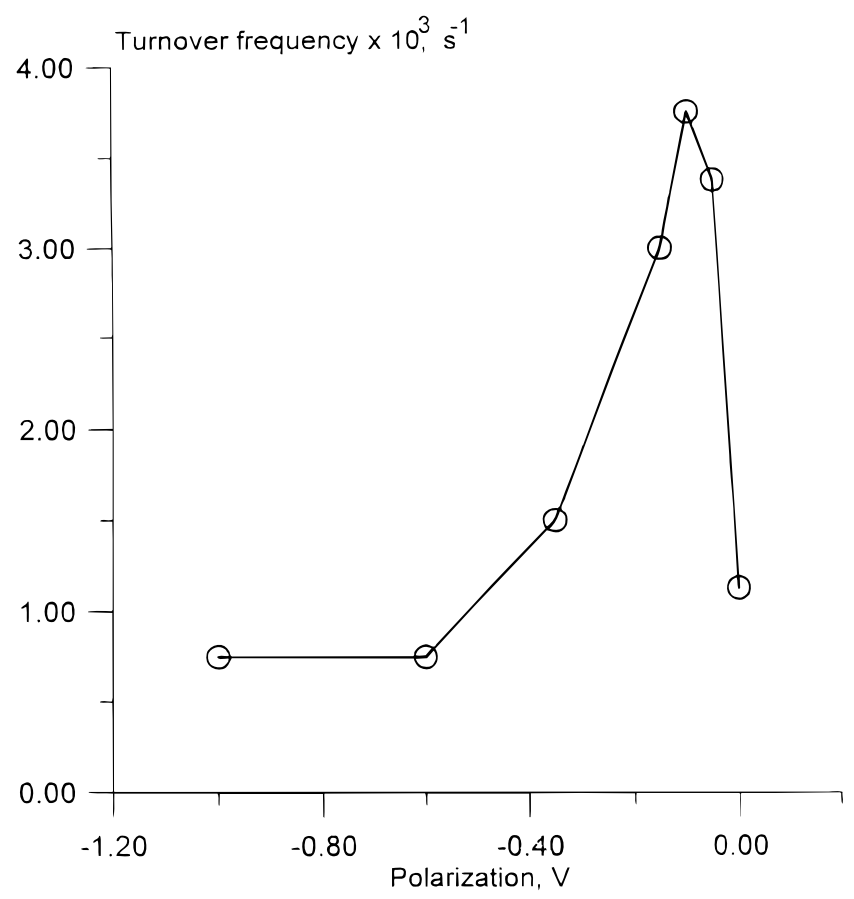

Figure 6. Turnover frequency of the $\mathrm{SO}_{2}$ catalytic oxidation [mol. $\mathrm{SO}_{2}$ (conv.) $\left./ \mathrm{mol} \mathrm{V}_{2} \mathrm{O}_{5} / \mathrm{s}\right] v s$. the working electrode polarization for the VK-58 catalyst (Haldor Topsøe A/S) at $400^{\circ} \mathrm{C}$.

with a molar ratio $\mathrm{M} / \mathrm{V}=4.25(\mathrm{M}=70 \mathrm{~mol} \% \mathrm{~K}+25 \mathrm{~mol} \% \mathrm{Cs}+$ $5 \mathrm{~mol} \% \mathrm{Na}$ ), using the same technology as for carbonate fuel cell experiments (Fig. 5). The cell was used in the vertical position. The catalyst was used as a powder mixed with $\mathrm{K}_{2} \mathrm{~S}_{2} \mathrm{O}_{7}$ and pressed between the upper gold working electrode and the porous quartz diaphragm. Molten $\mathrm{K}_{2} \mathrm{~S}_{2} \mathrm{O}_{7}$ which filled the catalyst and pores of the diaphragm served as the electrolyte between the gold working electrode and the gold counter electrode. The open-circuit potential of the $\mathrm{SO}_{2}, \mathrm{O}_{2} / \mathrm{Au}$ working electrode (cell in Fig. 5) was $-0.287 \mathrm{~V}$ against $\mathrm{O}_{2} / \mathrm{Au}$ counter (and reference) electrode.

It was shown that the catalyst activity could be increased up to four times by low (below $-0.2 \mathrm{~V}$ ) negative polarization (Fig. 6). Higher negative polarization causes no, or only a slightly negative effect $(\sim-1.0 \mathrm{~V})$. The highest promotion effect took place at a potential corresponding to the initial stages of the $\mathrm{V}(\mathrm{V}) \rightarrow \mathrm{V}(\mathrm{IV})$ reduction (Fig. 7). When $\mathrm{V}(\mathrm{V}) \rightarrow \mathrm{V}(\mathrm{IV})$ was moved too far from the equilibrium by a strong negative polarization the promotion effect was suppressed.

\section{Conclusions}

The effect of electrochemical promotion of the sulfur dioxide catalytic oxidation was studied in $\mathrm{V}_{2} \mathrm{O}_{5}-\mathrm{K}_{2} \mathrm{~S}_{2} \mathrm{O}_{7}$ melts in the temperature range $440-460^{\circ} \mathrm{C}$.

It has been shown that there are two negative polarization promotion areas with maximum effects at approximately -0.1 and $-0.2 \mathrm{~V}$, and one positive polarization promotion area with the maximum effect between 0.1 and $0.3 \mathrm{~V}$. The promotion effects at negative polarization are completely non-Faradaic. All the promotion effects have been explained as mainly the effect of charging of the double electric layer at the gold electrode. The effect at $-0.2 \mathrm{~V}$ depends also on the $\mathrm{V}_{2} \mathrm{O}_{5}$ concentration and is more pronounced at higher $\mathrm{V}_{2} \mathrm{O}_{5}$ concentrations. This has been ascribed to the destruction of the vanadium polymeric chains caused by the negative charge on the electrode.

The Faradaic part of the promotion effect in the conditions of positive polarization has been explained as the electrochemical pushing of the $\mathrm{V}(\mathrm{V}) \leftrightarrow \mathrm{V}(\mathrm{IV})$ equilibrium in direction of $\mathrm{V}(\mathrm{V})$ formation.

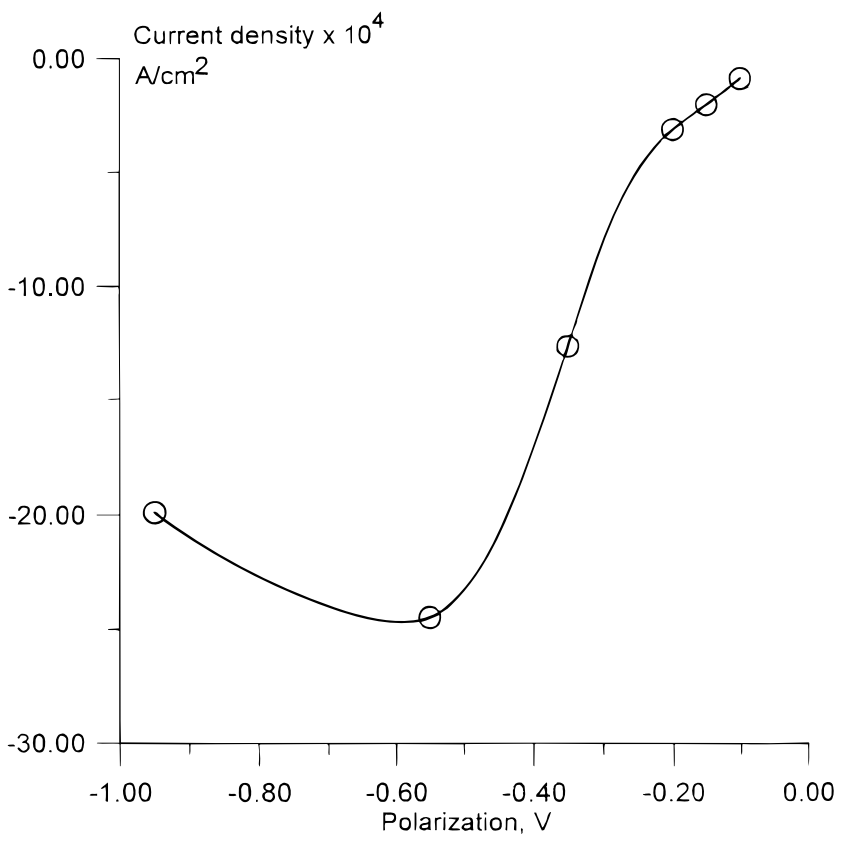

Figure 7. A stationary polarization curve obtained during the electrochemical experiment with VK-58 catalyst (Haldor Topsøe A/S) at $440^{\circ} \mathrm{C}$.

\section{Acknowledgments}

This investigation has been supported by the EEC BRITEEURAM II project BRE2.CT93.0047, the Danish Natural Science Research Council project no. 9502161, the Danish Natural Science Research Council THOR-project no. 9700900, and the Danish Research Councils ICAT-project no. 9702636.

We also want to express our gratitude to Dr. B. K. Andersen for useful discussions and advice.

The Technical University of Denmark assisted in meeting the publication costs of this article.

\section{References}

1. N. J. Bjerrum, I. M. Petrushina, and R. W. Berg, J. Electrochem. Soc., 142, 1806 (1995).

2. I. M. Petrushina, N. J. Bjerrum, R. W. Berg, and F. Cappeln, J. Electrochem. Soc., 144, $532(1997)$

3. I. M. Petrushina, N. J. Bjerrum, and F. Cappeln, J. Electrochem. Soc., 145, 3721 (1998).

4. W. D. Mross, Catal. Rev. Sci. Eng., 25, 591 (1983).

5. C. Wagner, Adv. Cata., 21, 323 (1970).

6. C. G. Vayenas, Solid State Ionics, 28, 1521 (1988).

7. M. Stoukides, Ind. Eng. Chem. Res., 27, 1745 (1988).

8. P. J. Gellings, H. S. A. Koopmans, and A. J. Burggraaf, Appl. Catal., 39, 1 (1988),

9. C. G. Vayenas, S. Bebelis, and S. Ladas, Nature, 343, 625 (1990).

10. G. C. Vayenas, M. M. Jakis, S. I. Bebelis, and S. G. Neophytides, in Modern Aspects of Electrochemistry, Vol. 129, J. O'M. Bockris, B. E. Conway, and R. E. White, Editors, pp. 57-202, Plenum Press, New York (1996).

11. J. Pritchard, Nature, 434, 592 (1990).

12. Yu. S. Chekryshkin, P. S. Dukhanin, A. P. Khaimenov, and A. A. Fyodorov, in Molten Salt Chemistry and Technology 1998, H. Wendt, Editor, p. 497, Trans. Tech. Publications Ltd., Uetikon-Zuerich (1998).

13. N. H. Hansen, R. Fehrman, and N. J. Bjerrum, Inorg. Chem., 21, 744 (1982).

14. D. S. Schmidt, J. Winnick, S. Boghosian, and R. Fehrmann, J. Electrochem. Soc., 146, 1060 (1999)

15. H. A. Andreasen, N. J. Bjerrum, and C. E. Foverskov, Rev. Sci. Instrum., 48, 1340 (1977).

16. V. A. Mastikhin, O. B. Lapina, L. G. Simonova, and B. S. Baldginimaev, Rasplavy (Melts), 2, 21 (1990).

17. P. Mars and J. G. H. Maessen, J. Catal., 10, 1 (1968).

18. A. R. Glueck and C. N. Kenney, Chem. Eng. Sci., 23, 1257 (1968).

19. J. Villadsen, and H. Livbjerg, Catal. Rev.-Sci. Eng., 21, 73 (1980).

20. H. Jensen-Holm, Ph.D. Thesis, Technical University of Denmark, Lyngby (1978).

21. G. K. Boreskov, A. A. Inova, B. S. Balzhinimaev, and L. M. Karnatovskaya, React. Kinet. Catal. Lett., 14, 25 (1980).

22. B. S. Balzhinimaev, V. E. Ponomarev, G. K. Boreskov, and A. A. Ivanov, React. Kinet. Catal. Lett., 25, 219 (1984). 